\title{
Odczyny popromienne w radioterapii oraz popromienne zapalenie skóry
}

\section{Side effects in radiotherapy and radiation dermatitis}

\author{
Justyna Michalewska ${ }^{1}$ \\ ${ }^{1}$ Zakład Radioterapii I z Izbą Przyjęć, Wielkopolskie Centrum Onkologii
}

\section{Streszczenie}

Choroba nowotworowa jest wciąż bardzo aktualnym problemem. Zajmuje drugie miejsce wśród przyczyn zgonów na świecie. Chociaż medycyna dąży do ciągłego rozwoju metod walki z chorobą, nadal pozostaje ona problemem globalnym. Jedną z metod leczenia chorób onkologicznych jest radioterapia. Odgrywa ona istotną rolę w leczeniu chorób nowotworowych. Jednak pomimo swojej skuteczności ma również działania niepożądane. Ciągły rozwój technologii i wykorzystywanie nowszej aparatury nadal nie rozwiązało problemu reakcji popromiennych, które towarzyszą radioterapii. Odczyny popromienne pojawiają się w przypadku przekroczenia dawki tolerancji, która jest indywidualna dla każdego narządu. Poniższa praca opisuje tematykę odczynów popromiennych, wyindukowanych na skutek leczenia radioterapeutycznego. Zawiera ich podział, krótką patogenezę oraz skale wykorzystywane do opisu odczynów popromiennych.

\begin{abstract}
Cancer is still a very current problem. It is the second leading cause of death worldwide. Although medicine seeks to continually develop methods for fighting the disease, it remains a global issue. One of the treatments for oncological diseases is radiotherapy. It plays an important role in the treatment of cancer. However, in spite of its effectiveness, it also has side effects. The continuous development of technology and the use of newer equipment have not as yet resolved the problem of radiation reactions that accompany radiotherapy. Radiation reactions occur when the tolerance dose is exceeded, which is individual for each organ. This work reports on radiation reactions arising from radiotherapy. It contains the division, short pathogenesis and scales used to describe the radiation reactions.
\end{abstract}

Słowa kluczowe: nowotwór; odczyny popromienne; popromienne zapalenie skóry; radioterapia

Keywords: cancer; side effect; radiation dermatitis; radiotherapy

Adres do korespondencji

mgr Justyna Michalewska

Młodszy Asystent Elektroradiologii

Oddział Radioterapii Onkologicznej I z Izbą Przyjęć

Wielkopolskie Centrum Onkologii, ul. Garbary 15, 61-866 Poznań, Polska

Telefon: +48618850867

e-mail: j_michalewska@wp.pl 


\section{Wstęp}

Pomimo rozwoju technologii oraz wykorzystywania coraz nowszych metod leczenia, choroby nowotworowe nadal zajmują drugie miejsce wśród przyczyn zgonów na świecie. Wyżej znalazły się jedynie choroby układu sercowo-naczyniowego. Wykrycie nowotworu we wczesnym stadium, a także zastosowanie odpowiedniego leczenia pozwala niekiedy na całkowitą remisję [1]. Chirurgia, radioterapia oraz chemioterapia są metodami stosowanymi do leczenia nowotworów złośliwych [2]. Radioterapia wykorzystuje promieniowanie jonizujące, którego celem jest zniszczenie komórek nowotworowych. W tym celu podaje się pacjentowi możliwie wysoką dawkę promieniowania jonizującego na zmienione nowotworowo tkanki, przy jednoczesnym zminimalizowaniu dawki, którą otrzymają komórki zdrowe. Jest to możliwe dzięki zastosowaniu specjalistycznej aparatury do planowania leczenia, prowadzenia, a także kontroli terapii z wykorzystaniem promieniowania jonizującego [3]. Radioterapia jest metodą ulegającą bardzo szybko postępowi technologicznemu. Coraz nowsze aparaty służące do realizacji leczenia, a także wykorzystanie nowoczesnych technik, takich jak IMRT (ang. Intensity Modulated Radiation Therapy), czyli modulacja intensywności wiązki lub VMAT (ang. Volumetric Modulated Arc Therapy), zwana w polskiej nomenklaturze terapią wielołukową, pozwoliły znacząco obniżyć występowanie skutków ubocznych radioterapii. U pacjentów leczonych terapią z wykorzystaniem promieniowania jonizującego często pojawiają się działania niepożądane - odpowiedź ze strony skóry, przejawiająca się w postaci odczynu popromiennego, np. zaczerwienienie skóry [2].Odczyn powstający na skutek radioterapii spowodowany jest śmiercią komórek najbardziej narażonych na działanie promieniowania jonizującego. Zaczerwienienie występuje w miejscu bezpośrednio poddawanym radioterapii.Negatywne skutki wywołane radioterapią mogą utrzymywać się od kilku tygodni do nawet kilku lat po zakończeniu leczenia [3]. Niepożądane odczyny popromienne pojawiają się najczęściej przypadku nowotworów zlokalizowanych w obszarze głowy i szyi, krocza, a także piersi [2].

\section{Odczyny popromienne}

Działaniami niepożądanymi jakie wywołuje radioterapia są odczyny popromienne. Ryzyko wystąpienia odczynu wzrasta w przypadku leczenia skojarzonego - połączenia radioterapii z chemioterapią. Powodem wystąpienia reakcji popromiennej jest napromienienie tkanek zdrowych, które znajdują się w obszarze leczenia. Niestety nie istnieje możliwość poddania radioterapii tylko tkanek zmienionych nowotworowo. Promieniowanie jonizujące wpływa również na komórki niezmienione chorobowo. Skutkuje to wystąpieniem działań niepożądanych u pacjentów poddanych radioterapii. Można wyróżnić dwa typy powikłań: wczesne, zwane również ostrymi oraz późne. Grupa, do której zostaną sklasyfikowane zależy od czasu w jakim pojawiła się reakcja. Wczesne działanie niepożądane może wystąpić już w trakcie leczenia i bezpośrednio po jego zakończeniu do 3-6 miesięcy. Późny odczyn występuje od 6 miesięcy do nawet kilku lat od zakończenia leczenia $[4,5]$.

Wczesny odczyn powstaje w wyniku wielu różnych nieprawidłowości czynnościowych oraz morfologicznych. Procesy te zachodzą w komórkach oraz ich przestrzeniach, wywołując dużo kluczowych objawów ujawniających się podczas radioterapii oraz po jej zakończeniu [3]. Powikłania wczesne mają charakter względnie krótkotrwały i najczęściej są odwracalne, przy wdrożeniu odpowiedniego leczenia wspomagającego [6]. Aktualne wiadomo jednak, że wczesny odczyn popromienny może przekształcić się w tzw. następczy późny odczyn popromienny, który stanowi poważne powikłanie kliniczne. Następczy późny odczyn popromienny został opisany w 1992 roku. Zdefiniowano go jako morfologicznie przypominający odczyn późny, jednak uwidaczniający się wcześniej. Przyczyną takiego zjawiska jest zbyt wysoka dawka tygodniowa. Dochodzi do pojawienia się infekcji bakteryjnej bądź uszkodzenia mechanicznego, w wyniku czego nie dochodzi do gojenia, jednocześnie doprowadzając do powstania następczej martwicy.

Wystąpienie późnego odczynu jest ściśle powiązane z dawką promieniowania jaką otrzymał pacjent. Szybkośćujawnienia sięodczynu rośnie, wrazzewzrostem dawki [4]. Prawdopodobieństwo wystąpienia reakcji popromiennej, jej nasilenie oraz charakter odczynu uwarunkowany jest czynnikami zewnątrzpochodnymi. Określają one odpowiedź tkanek prawidłowych na promieniowanie jonizujące. Wyróżnia się dwie grupy czynników. Pierwsza, mająca związek z radioterapią, powiązana jest z rodzajem oraz energią wykorzystaną do leczenia, dawką całkowitą i frakcyjną, a także czasem leczenia. Drugą grupę stanowią czynniki związane 
z pacjentem. Istotne są tu przebyte zabiegi lub urazy w obszarze napromienianym lub współistnienie innych dysfunkcji internistycznych - stany związane z niewydolnością krążenia na skutek cukrzycy, chorób naczyń krwionośnych oraz nadciśnieniem tętniczym [3].

\section{Odczyny miejscowe i ogólne}

W zależności od czasu, w jakim wystąpiły działania niepożądane można wyróżnić wczesne i późne odczyny miejscowe oraz powikłania ogólnoustrojowe. Odczyny wczesne odnoszą się do miejsca, które zostało bezpośrednio poddane działaniu promieniowania jonizującego [5,6]Mogą one wystąpić już w trakcie radioterapii lub pojawić się $\mathrm{w}$ ciągu kilku tygodniu od zakończenia leczenia. Przykładem jest rumień skóry, suche lub wilgotne łuszczenie skóry, nudności, biegunka lub zapalenie błon śluzowych. Wczesne negatywne skutki działania radioterapii są tymczasowe. Przy odpowiedniej opiece mogą one ustąpić [7]. Natomiast późne to zwłóknienia, przetoki, atrofia, uszkodzenia naczyń krwionośnych, włókien nerwowych lub martwica kości, której czynnikiem indukującym było zastosowanie promieniowania jonizującego Późne odczyny są jednak nieodwracalne [5,7]. Powikłania ogólnoustrojowe pojawiają się na skutek oddziaływania radioterapii na organizm. Najczęściej przejawiają się uszkodzeniem szpiku kostnego (mielosupresja), nudnościami, wymiotami, podwyższoną temperaturą oraz objawami dyspeptycznymi. Najpoważniejszym, jednak występującym rzadko późnym powikłaniem po radioterapii jest wtórny nowotwór, wyindukowany w miejscu napromienianym lub w jego bliskim sąsiedztwie $[5,6]$.

\section{Patogeneza powstawania reakcji popromiennych}

Celem radioterapii jest doprowadzenie do śmierci komórki w wyniku uszkodzenia jej DNA. Promieniowanie jonizujące powoduje jonizację materii. Absorpcja promieniowania przez cząsteczkę wody doprowadza do oderwania elektronu od atomu lub jej wzbudzenia oraz rozpadu cząsteczki wody na rodnik wodorowy oraz hydroksylowy. W wyniku hydrolizy wody zostają utworzone wolne rodniki, które doprowadzają do pęknięć w strukturze DNA[6,8]. Działanie promieniowania jonizującego opisują dwa mechanizmy - bezpośredni oraz pośredni [9].

Mechanizm bezpośredni - jego rolą jest defekt najbardziej wrażliwych elementów komórki, np. DNA lub błony komórkowej za pośrednictwem wolnego elektronu, który został wytworzony w wyniku absorpcji fotonu lub promieniowania korpuskularnego [5]. Energia promieniowania zostaje zdeponowana bezpośrednio w makrocząsteczce [8].

Mechanizm pośredni powstaje na skutek pochłaniania energii promieniowania jonizującego przez ośrodek, który otacza makrocząsteczkę biologiczną. W wyniku tego działania zostają utworzone wolne rodniki, mogące doprowadzić do uszkodzenia struktur komórki [8,10]. Pojedyncza depozycja energii może doprowadzić do wytworzenia wielu wolnych rodników. Nie są one jednak wytwarzane jednorodnie, a zasięg ich działania powiązany jest z szybkością dyfuzji [8]. Działanie pośrednie odpowiada za około $75 \%$ uszkodzeń popromiennych [5].

Mechanizm pośredni i bezpośredni wywołuje zmiany chemiczne w komórce, np. przerwanie wiązań wodorowych w strukturze DNA oraz biochemiczne, przykładem jest zaburzenie syntezy DNA oraz RNA w komórce. Opisane zmiany fizykochemiczne prowadzą do powstania określonych efektów biologicznych, ściśle związanych z otrzymaną dawką promieniowania [10]. Kliniczny obraz powikłań popromiennych jest wypadkową stopnia uszkodzenia komórki i upośledzenia jej zdolności do regeneracji [6]. Proces ten dotyczy głównie komórek proliferujących [4]. Dysfunkcja podziałów komórki może być wywołana przez uszkodzenie chromosomów, opóźnienie mitozy, przesunięcie w cyklu komórkowym lub mutacje. Defekty metaboliczne odnoszą się przede wszystkim do zmian przepuszczalności błony komórkowej, zaburzenia syntezy białek oraz czynności enzymów [10]. Największe znaczenie terapeutyczne mają zmiany doprowadzające do śmierci komórki - uzyskanie efektu letalnego [4]. Przykładem mogą być uszkodzenia chromosomów, które zahamowują proces podziału komórek. Jednak komórki posiadają mechanizmy naprawcze, które mogą skorygować szkodliwe działanie promieniowania. Mechanizm ten odnosi się zarówno do uszkodzeń potencjalnie letalnych, subletalnych, a także nieletalnych. Uszkodzenia subletalne są bardzo istotne klinicznie, ponieważ mogą być przyczyną późnych, negatywnych efektów radioterapii [10]. 


\section{Kliniczna klasyfikacja odczynów}

Do oceny wyników leczenia powinno uwzględniać się stopień remisji nowotworu oraz opis reakcji popromiennych. Służy do tego specjalny system klasyfikacji odczynów popromiennych. System klasyfikacji powinien oceniać całościowo, czyli brać pod uwagę wszystkie uboczne skutki, które mogą wystąpić po radioterapii, umożliwiać powtarzalność - co oznacza taką samą ocenę objawów przez różnych obserwatorów lub tego samego w różnym przedziale czasowym, a także zapewniać odpowiednią czułość, co oznacza, że system powinien ukazywać różnice $\mathrm{w}$ różnych metodach wykorzystywanych $\mathrm{w}$ radioterapii. Dostępne są różne systemy klasyfikacji. Najczęściej wykorzystywana jest skala RTOG / EORTC, skala LENT SOMA i Common Toxicity Criteria, mniej wykorzystywana jest skala Dische’a, Franco-ItalianGlossary, system jednostek nasilenia i czasu oraz najbardziej przydatny system do oceny odczynu skóry - NCI [9,11].

- Skala RTOG / EORTC (RadiationTherapyOncologyGroup / European Organization for Research and Treatment of Cancer) - pozwala na ocenę wczesnych i późnych odczynów popromiennych. Dla poszczególnych tkanek i narządów opracowano skalę zintensyfikowania objawów od Go - co oznacza brak odczynu, poprzez G1-G4 - różne nasilenie odczynu, do G5 - oznaczającego zgon spowodowany powikłaniami popromiennymi.

- Skala LENT SOMA (Late Effects of Normal Tissue; Subjective, Objective, Management, Analytic) - jest to skala dedykowana późnym odczynom popromiennym w tkankach prawidłowych (LENT). Składa się z części subiektywnej, której oceny dokonuje pacjent oraz obiektywnej oceny wykonywanej przez lekarza. Uwzględnienia postępowania w kierunku lagodzenia objawów, a także metody wykorzystywane do oceny funkcji narządów. Oceny dokonuje się w skali od G1 do G4. Brany jest tu także pod uwagę łączny stopień nasilenia reakcji popromiennej oraz nasilenie odczynu w czasie.

- Skala Common Toxicity Criteria - zaproponowana do rozpoznania wczesnych powikłań popromiennych. W skali tej uwzględniono 260 objawów, odniesionych do 24 narządów i układów. Symptomy oceniane są od Go - co oznacza, że odczyn nie wystąpil, przez G1-G4 - różna intensywność odczynów, do G5 - oznaczającego zgon.

- Skala Dische'a - została utworzona jako następstwo obserwacji odczynu popromiennego występującego $\mathrm{w}$ błonie śluzowej jamy ustnej, gardła oraz krtani w trakcie radioterapii hyperfrakcjonowanej. Skala ta poddaje ocenie objawy, ich intensywność oraz leczenie, przydzielając odpowiednio od 1 do 3 punktów. Decydujący wynik określa sumę wszystkich osiągniętych punktów.

- Jednostki nasilenia i czasu (STU - Severity-Time Units) - zostały opracowane na skutek obserwacji dokonanych w czasie niekonwencjonalnego sposobu dostarczania dawki w radioterapii głowy i szyi. Jednostki nasilenia i czasu pozwalają dokonać oceny wczesnego odczynu pochodzącego ze strony błony śluzowej. System ten bierze pod uwagę czas pojawienia się odczynu, czas trwania jego największego nasilenia oraz szybkość gojenia. Wyniki zaprezentowane są przy pomocy wykresu w postaci krzywej.

- Skala NCI (National Cancer Institute) - to 5-stopniowa skala, której pierwszy stopień oznacza słaby rumień lub suche łuszczenie, a ostatni oznacza zgon.

Przeprowadzonoliczne badania porównujące różneklasyfikacje odczynów, jednak nie istnieje ujednolicony, jednoznaczny system oceny odczynów popromiennych [9,11].

\section{Popromienne zapalenie skóry}

Pomimo ciągłego rozwoju technologii i aparatury, rozpowszechnienia w leczeniu przyspieszaczy wysokoenergetycznych, wciąż prawie 90\% chorych uskarża się na dolegliwości i objawy skórne, które są następstwem działania promieniowania jonizującego [12]. Wzrost dawki całkowitej wpływa niekorzystnie na zdolność odbudowy tkanki zdrowej. Im wyższa dawka, tym zdolność regeneracji tkanki prawidłowej spada [11]. Reakcje popromienne w postaci stanu zapalnego skóry stają się widoczne w większości przypadków 1-4 tygodnie od rozpoczęcia radioterapii, utrzymują się przez cały okres leczenia i mogą być jeszcze widoczne przez około 2-4 tygodnie po zakończeniu radioterapii. W pierwszym etapie popromienne zapalenie skóry przejawia się zaczerwienieniem o zróżnicowanym stopniu nasilenia, wraz z łuszczeniem się naskórka „na 
sucho” lub „na mokro”. Złuszczanie naskórka ukazuje defekt komórek warstwy podstawnej naskórka, a także gruczołów łojowych i potowych znajdujących się w skórze właściwej [11]. Złuszczaniu na wilgotno towarzyszy surowiczy wysięk i ubytek aż do warstwy właściwej skóry. Odczyn późny skórny uzależniony jest głównie, tak jak inne reakcje popromienne od wysokości dawki frakcyjnej i całkowitej. Przykładem późnych reakcji popromiennych są: zanik skóry właściwej, zwłóknienia, przebarwienia, teleangiektazje lub martwica. Teleangiektazje i nekroza mogą uwidocznić się 6-12 miesięcy od zakończenia leczenia. Miejscowe obumarcie komórek spowodowane jest podaniem zbyt wysokiej dawki całkowitej, co doprowadza do uszkodzenia naczyń krwionośnych. W konsekwencji występuje niedokrwienie, dalej skutkujące śmiercią komórki [12]. Za pojawienie się odczynu popromiennego odpowiada również lokalizacja pola poddawana radioterapii. Jeśli w obszarze napromienianym znajdują się dwie powierzchnie skóry, np. krocze czy pierś lub występuje cienka warstwa naskórka, np. twarz, pacha bądź struktura skóry została już wcześniej w tym miejscu naruszona przez zabiegi chirurgiczne, oparzenia lub urazy, odczyn popromienny w takich miejscach będzie większy[11].

W czasie wykorzystywania do radioterapii aparatów ortowoltowych skóra stanowiła jeden z najważniejszych organów krytycznych, co nie pozwalało na podanie wysokich dawek na obszar guza. Wynikało to z rozkładu procentowej dawki głębokiej, która osiągała maksimum na powierzchni skóry. Zastosowanie wysokoenergetycznych akceleratorów liniowych wpłynęło na znaczne ograniczenie pojawiania się popromiennych reakcji skórnych [12].

Do oceny stopnia nasilenia ostrego i późnego odczynu popromiennego skóry wybiera się czterostopniową skalę RTOG/EORTC lub NCI [12].

Tabela 1. Wczesny odczyn popromienny. Skala RTOG i NCI (źródło [12])

\begin{tabular}{|c|c|c|}
\hline Stopień & Skala RTOG & Skala NCI \\
\hline o & Brak zmian & Brak zmian \\
\hline I & $\begin{array}{c}\text { Plamki i/lub wysypka drobnogrudkowa lub } \\
\text { zaczerwienienie, bezobjawowe }\end{array}$ & tagodne zaczerwienienie lub suche złuszczanie \\
\hline II & $\begin{array}{c}\text { Plamki i/lub wysypka drobnogrudkowa lub silne } \\
\text { zaczerwienienie ze świądem }\end{array}$ & $\begin{array}{c}\text { Średnie zaczerwienienie, ograniczone złuszczanie na } \\
\text { wilgotno, obrzęk o średnim nasileniu }\end{array}$ \\
\hline III & $\begin{array}{c}\text { Uogólniona objawowa wysypka grudkowa, } \\
\text { przebarwienia lub wysypka pęcherzykowa }\end{array}$ & $\begin{array}{c}\text { Zlewne złuszczenia na wilgotno w okolicach innych } \\
\text { niż fałdy skórne, krwawienia po małym urazie }\end{array}$ \\
\hline IV & Zluszczające lub wrzodziejące zapalenie skóry & $\begin{array}{c}\text { Martwica i/lub owrzodzenia ze ścieńczeniem skóry, } \\
\text { samoistne krwawienia }\end{array}$ \\
\hline
\end{tabular}

\section{Leczenie popromiennego zapalenia skóry}

Jest ono uzależnione od stopnia uszkodzenia skóry i polega przede wszystkim na ochronie obszaru poddawanego radioterapii, wystrzeganiu się podrażnień, urazów mechanicznych, należy chronić skórę przed promieniowaniem słonecznym oraz ponownym napromienianiem [12].

\section{Higiena obszaru napromienianego}

Pacjentom w trakcie radioterapii zaleca się mycie skóry poddawanej radioterapii letnią wodą z dodatkiem łagodnego mydła. Udowodniono, że wpływa to pozytywnie na skórę poddawaną radioterapii. Odczyny skórne są mniejsze, niż u pacjentów, którzy unikali zamaczania tego obszaru [11]. W trakcie kursu radioterapii niedopuszczalne jest używanie kosmetyków oczyszczających skórę, w szczególności tych, w których skład wchodzi alkohol [12]. 


\section{Podsumowanie}

Radioterapia jest metodą leczenia zmian nowotworowych, której niestety nie da się odgraniczyć jedynie do obszaru guza. Leczenie z wykorzystaniem promieniowania jonizującego może być przyczyną pojawiania się działań niepożądanych. Ze względu na czas, w jakim wystąpią można podzielić je na wczesne i późne. Jednym z nich jest wyidukowanie reakcji popromiennej w tkankach niezmienionych chorobowo. Jest to jedno z najczęściej występujących powikłań nawet $\mathrm{w}$ trakcie radioterapii. Ważnym problemem pojawiającym się w przypadku tematyki odczynów popromiennych jest brak ujednoliconej skali, wykorzystywanej do opisania stopnia nasilenia zmian. Nowe badania powinny pozwolić poznać dokładniej mechanizmy powstawania odczynów popromiennych i opracować metody ich leczenia.

\section{Konflikt interesu / Conflict of interest}

Nie występuje / None

\section{Etyka / Ethics}

Treści przedstawione w artykule są zgodne z zasadami Deklaracji Helsińskiej, dyrektywami EU oraz ujednoliconymi wymaganiami dla czasopism biomedycznych.

\section{Piśmiennictwo / References}

[1] Wożakowska-Kapłon B, Szymczyk R, Buda S, Biskup P. Przebyta terapia onkologiczna - niedoceniany czynnik ryzyka choroby wieńcowej? Opis trzech przypadków ostrego zespołu wieńcowego u kobiet po przebytej radio- i chemioterapii. Kardiol Pol 2008; 66: 415-419.

[2] Topczewska-Bruns J, Filipowski TM, Demska M. Pielęgnacja i ochrona skóry w trakcie i po radioterapii. Opieka onkologiczna $\mathrm{Nr}$ 2/2014.

[3] Biedka M, Dutsch-Wicherek M. Odczyn popromienny u chorego z rakiem krtani poddanego pooperacyjnej uzupełniającej radioterapii, $\mathrm{w}$ trakcie leczenia immunosupresyjnego po przeszczepie nerki. Otorynolaryngologia 2015, 14(2): 108-116.

[4] Słonina D. Odpowiedź guza nowotworowego i tkanek prawidłowych na napromienianie. Rozdz w: Planowanie leczenia i dozymetria w radioterapii. Pod red: Malickiego J, Ślosarka K, Via Medica Gdańsk 2016, 311-315.

[5] Dyczka J, Jessem J, Fijuth J. Radioterapia nowotworów. Rozdz w: Onkologia podręcznik dla studentów i lekarzy. Pod red: Kordka R, Via Medica Gdańsk 2013, 75-84.

[6] Ziółkowska E, Biedka M, Windorbska W. Odczyn popromienny u chorych na raka regionu głowy i szyi: mechanizmy i konsekwencje. Otorynolaryngologia 2011, 10(4): 147-153.

[7] Bentzen SM. Preventing or reducing late side effects of radiation therapy: radiobiology meets molecular pathology. Nat Rev Cancer. 2006 Sep; 6(9): 702-13.

[8] Bourguign MH, Gisone PA, Perez MR, Michelin S, Dubner D, Di Giorgio M, Carosella ED. Eur J Nucl Med Mol Imaging (2005) vol. 32: 351-368.

[9] Kornafel J, Izmajłowicz B. Objawy niepożądane chemioterapii i radioterapii. Rozdz w: Ginekologia onkologiczna - wydanie kieszonkowe. Red: Markowska J, Mądry R, MediPharm Polska Wrocław 2008, 231-250.

[10] Dyczka J, Jassem J. Radioterapia nowotworów. Via Medica Pomorski Magazyn Lekarski 2004; 132(2): 18-21.

[11] Topczewska-Bruns J, Filipowski T. Leczenie popromiennego zapalenia skóry w świetle medycyny opartej na faktach. Współczesna Onkologia (2010) vol. 14; 3 (223-228).

[12] Kowalski D. Zmiany skórne: towarzyszące chemioterapii, terapiom ukierunkowanym molekularnie, popromienne. Rozdz w: Leczenie wspomagające w onkologii praktyczny przewodnik dla lekarzy. Red: Jassem J, Krzakowski M, Zaucha R, Via Medica Gdańsk 2013, 128-147. 